Check for updates

Montreal

Cite this as: $B M J 2021 ; 373: n 1188$ http://dx.doi.org/10.1136/bmj.n1188 Published: 10 May 2021

\title{
Covid-19: Study claims real global deaths are twice official figures
}

\section{Owen Dyer}

Global deaths from covid-19 are not 3.27 million, as official figures suggest, but 6.93 million up to 3 May, a new analysis based on changes in overall mortality claims. $^{1}$

The virus is claiming about 33 ooo lives a day around the world, more than twice reported figures, according to the study by the Institute for Health Metrics and Evaluation (IHME) at the University of Washington. The study predicts that the pandemic's true overall toll will reach 9.43 million deaths by 1 September. ${ }^{2}$

In the UK, the researchers estimated, the true covid death toll up to May 2021 was not 150519 as officially reported, but 209661 . They estimated the true US death toll at 905289 , compared with an official figure of 574043 .

The institute predicts a further 44000 US deaths by September, ${ }^{3}$ and only 750 deaths in the UK, ${ }^{4}$ because of its lower rate of vaccine refusal. India is forecast to lose a further 842000 people in that period. ${ }^{5}$

Rochelle Walensky, director of the US Centers for Disease Control (CDC), told a media briefing that her agency will study the report, which bases its conclusions on the past year's deviations from expected overall mortality. "We will look at this carefully and decide whether to count them as excess deaths or to count them as covid specific deaths," she said. The CDC's upper bound estimate for total excess US deaths since March 2020 is 690138 . Hence the IHME's estimate of 905289 covid deaths is only possible if deaths from non-covid causes were fewer than usual over the past year.

Deaths from non-covid causes declined, the researchers write, because of fewer accidents during lockdowns, fewer deaths from other viruses such as influenza and measles, and fewer deaths from age related causes such as heart disease, since some frail elderly people who would have died from these causes were instead killed by covid-19.

A research letter published in the Journal of the American Medical Association last month found that deaths from some non-covid causes were higher than expected last year. ${ }^{6}$ It noted, however, that these excess reported deaths from heart disease and Alzheimer's disease mostly occurred during surges of covid-19.

The lead author of that research, Steven Woolf, criticised the IHME's new figures. "Their estimate of excess deaths is enormous and inconsistent with our research and others," he told National Public Radio. "There are a lot of assumptions and educated guesses built into their model."

The covid modelling of IHME drew worldwide attention in the early days of the pandemic when it was the forecaster most cited by the Trump administration. Its early models proved optimistic, and last summer it switched to a more conventional model which has since more accurately forecasted deaths.

\section{Eurasia's hidden toll}

Several of the countries identified by the IHME study as having greatly underreported covid deaths are those that have frequently been accused of undercounting by local media and doctors. Egypt, India, Mexico, and Russia figure prominently in such reports.

The IHME study gives India's covid death toll up to May as 654395 , which is 2.96 times the official figure. Mexico is attributed 617127 covid deaths, 2.83 times the official figure. In Egypt, the researchers estimate 170041 deaths, which is 12.6 times the official figure. Russia has the largest number of unreported covid deaths, they estimate, with a real death toll of 593 610 , which is 5.43 times the official estimate.

While some governments may attribute deaths in covid patients to comorbid conditions to keep their numbers low, the commonest reason for underreporting of covid deaths is inadequate testing, IHME's director Chris Murray told a media conference.

Countries with relatively accurate covid death reporting included Argentina, Australia, China, France, and Sweden, the researchers found. Turkey and Brazil are often accused of undercounting, but both were reporting more than half of their covid deaths. Many countries of central and eastern Europe were reporting only one death in three, a ratio also seen across sub-Saharan Africa. The worst undercounts were found in the Caucuses and former Soviet republics.

While the study's estimate of US deaths drew headlines, its numbers suggest that the heaviest toll of the pandemic is a largely hidden one that has fallen across eastern Europe and central Asia. Azerbaijan, with an official death rate of 457 per million on 3 May, has the world's highest real covid-19 death rate, the researchers estimated, at 6734 deaths per million people.

Institute for Health Metrics and Evaluation. Estimation of total mortality due to covid-19.6 May 2021. www.healthdata.org/special-analysis/estimation-excess-mortality-due-covid-19-and-scalars-reported-covid-19-deaths.

2 Institute for Health Metrics and Evaluation. Covid-19 results briefing: global. 5 May 2021. www.healthdata.org/sites/de-

fault/files/files/Projects/COVID/2021/1_briefing_Global_2.pdf.

Institute for Health Metrics and Evaluation. Covid-19 results briefing: United States of America. 6 May 2021. www.healthdata.org/sites/default/files/files/Projects/COVID/2021/102_briefing_United_States_of_America_17.pdf.

4 Institute for Health Metrics and Evaluation. Covid-19 results briefing: United Kingdom. 6 May 2021. www.healthdata.org/sites/de-

fault/files/files/Projects/COVID/2021/95_briefing_United_Kingdom_11.pdf.

5 Institute for Health Metrics and Evaluation. Covid-19 results briefing: India. 5 May 2021. www.healthdata.org/sites/de-

fault/files/files/Projects/COVID/2021/163_briefing_India_.pdf. 
6 Woolf SH, Chapman DA, Sabo RT, Zimmerman EB. Excess deaths from covid-19 and other causes in the US, March 12020 to January 22021. JAMA 2021;325:1786-9.

doi: 10.1001/jama 2021.5199 pmid: 33797550

This article is made freely available for use in accordance with BMJ's website terms and conditions for the duration of the covid-19 pandemic or until otherwise determined by BMJ. You may use, download and print the article for any lawful, non-commercial purpose (including text and data mining) provided that all copyright notices and trade marks are retained. 